\title{
A Cross-national Study of Student Teachers' Views about Intelligence: Similarities and Differences in England and Turkey
}

\author{
Dilek Ilhan-Beyaztas ${ }^{1, *}$, Elizabeth Dawson ${ }^{2}$ \\ ${ }^{1}$ Faculty of Education, Erzincan University, Turkey \\ ${ }^{2}$ Independent Researcher, England
}

Copyright $(2017$ by authors, all rights reserved. Authors agree that this article remains permanently open access under the terms of the Creative Commons Attribution License 4.0 International License

\begin{abstract}
A cross-national descriptive research method was used to explore Turkish and English student teachers' views about intelligence, and the factors which shape them. The "Adult Version of The Implicit Theory of Intelligence Scale" [1], and the Turkish version of this scale [2] were used to investigate the views of 114 English and 201 Turkish students of Primary Education. A semi-structured interview was also used with a sub-group of the students. The findings reveal that the Turkish students, on average, scored more highly in relation to entity intelligence theory than in relation to incremental intelligence theory, and the English students, on average, scored more highly in relation to incremental intelligence theory than to entity intelligence theory. In addition, when comparing the average scores in relation to incremental intelligence theory, the scores of the English students are significantly higher than those of the Turkish students.
\end{abstract}

Keywords Perceptions of Intelligence, Mindset Theory, Pre-Service Teacher Attitudes, Cultural Differences

\section{Introduction}

Theories about the dynamic nature of intelligence have been around for many years, and even in the 1990s Sternberg was suggesting that the idea that intelligence is malleable had become orthodoxy [3]. Over the last forty years, Dweck and her colleagues at Stanford University and beyond have gathered compelling evidence about the effect which beliefs about intelligence have on motivation, learning habits and goal-orientation - factors which in turn affect achievement $[1] ;[4] ;[5]$. They conclude that individuals with a "fixed mindset", who believe that intelligence is unchanging, tend to focus on results and performance, to regard mistakes negatively, to avoid challenge, and to fear failure.
Conversely, individuals with a "growth mindset", who believe that intelligence can be developed, are more willing to take risks, to focus on improvement and mastery, and to see their mistakes and failures as a necessary part of learning [4]; [6]. Consistent with this theory is the finding by Renaud-Dubé, Guay, Talbot, Taylor and Koestner [7] that a growth mindset attitude among US high schools students was related positively to their choices about continuing to higher levels of education, with its increased level of challenge and requirement of greater effort.

Student teachers have chosen to continue as learners in higher education, whilst simultaneously learning to teach. The views they hold about intelligence are therefore relevant both to their own experiences as learners and to their prospective pupils. There appears to be little research on the effect of student teachers' beliefs about intelligence on their own learning. However, unsurprisingly, studies indicate that the views teachers hold about intelligence affect their educational goals [8], their beliefs about their pupils' abilities, and their attitudes towards and treatment of them [9]. Research also indicates that teachers can in turn have an impact on the views about intelligence which pupils themselves hold [10]; [1].

Several studies of the views of student teachers in the United States have found that they are more likely to hold the view that intelligence can change rather than to believe that it is fixed [11];[12];[13]. In the UK, Asbury, Klassen, Bowyer-Crane, Kyriacou, and Nash [14] also found that student teachers at a UK university held broadly growth-mindset beliefs, but that those who had grown up in East Asia were less likely to do so. Moreover, those of East Asian origin were also less likely to hold growth mindset attitudes about their pupils. However, a recent study by İlhan-Beyaztaş and Hymer [2] found that Turkish student teachers across a range of academic disciplines were more likely to believe that intelligence is fixed rather than malleable. 
This current study therefore makes a further contribution to understanding about cultural/national differences in student teachers' views of intelligence. The comparative nature of this study is also timely: in recent years, the Turkish government has been striving to "harmonise" [15] its education system in relation to the European Union (EU) and its Common European Principles for Teacher Competences and Qualifications [16]. Turkey has also developed a set of Generic Teacher Competencies [17] with reference to the Standards for Qualified Teacher Status (Teacher' Development Agency, 2008) which pertained in England at that time [15]. The English Teaching Standards (and, previously, the Standards for Qualified Teacher Status), make no direct reference to teacher beliefs, though "high expectations" [18]; [19], and "goals that stretch and challenge" [20]; are requisites and could (but do not necessarily) imply that a growth-oriented view of intelligence. However, the Turkish Competencies include statements specifically about what teacher beliefs which relate to views about intelligence ("believing that all students can learn and achieve"; "believe that each student will be successful" - Turkish Republic Ministry of National Education, [17], A:2 and A:2.10).

This study proposes to answer the following questions:

1. How do Turkish and English primary education students perceive intelligence?

2. How do Turkish and English primary education students perceive intelligence based on their gender?

3. What views do Turkish and English primary education students hold about intelligence perceptions?

\section{Methods}

This is a cross-national study conducted to explore Turkish and English students' perceptions of intelligence. The study used both quantitative research and qualitative research tools.

\subsection{Participant}

In total, 315 students whose major fields of study were in primary education volunteered to participate in the quantitative part of the study. 201 students (132 females, 69 males) from Turkey and 114 students ( 81 females, 33 males ) from England were selected through stratified random sampling. In addition, 10 student volunteers (also undergraduate students in primary education) took part in semi-structured interviews.

\subsection{Data Collection Tools}

In this study, the "Adult Version of The Implicit Theory of Intelligence Scale" developed by Dweck [1] was used to investigate the English students' perceptions of intelligence.
The study also used the "Adult Version of The Implicit Theory of Intelligence Scale" which was adapted into Turkish by İlhan-Beyaztaş and Hymer [2], in order to explore the Turkish students' perceptions of intelligence. The Adult Version of The Implicit Theory of Intelligence scale is a Likert scale developed by Dweck [1] to determine the beliefs learners hold about the nature of intelligence. The original scale is a 6 point Likert-type scale ranging from "strongly agree" (1) to "strongly disagree" (6). The sub dimensions of the scale are entity (items 1, 2, 4 and 6: for example: "You can learn new things, but you can't really change your basic intelligence"), and incremental (items 3, 5 , 7 and 8: for example: "You can change even your basic intelligence level considerably").

In order to explore students' perception of intelligence further, a semi-structured interview was developed by the researchers. Drawing on the relevant literature, seven draft questions were prepared. These questions were revised following the suggestions of three subject area experts, a Turkish field expert, and a measurement-evaluation expert. The interview form consisting of 7 questions was finalized based on experts' recommendations. The final interview form consisted of two parts. The first part covered demographic questions, while the second part consisted of questions examining students' opinions of their perceptions of intelligence.

\subsection{Data Collection Process and Analysis}

The analysis of the study includes descriptive statistics such as arithmetic average and standard deviation values in order to specify students' perceptions of intelligence. The multivariate analysis of variance (MANOVA) was run to test the variations through students' perceptions of intelligence in terms of students' gender and country. One of the multi variable test statistics (Wilk's Lambda statistics) was used in order to determine whether there was a difference between the group averages according to any dependent variables. The F statistic was used in order to determine which dependent variables caused the difference between the groups. When differences were found between the groups, LSD comparison tests were used by controlling the equivalence of variances and the number of categories.

Additionally, the responses of the students in the interviews were subjected to content and thematic analysis. The following steps took place during the analysis process:

1. Ten students were interviewed to gain a deeper understanding of their perceptions of intelligence. Interviews were recorded with the permission of the participants. The recorded interviews were transcribed.

2. Before coding, all transcripts were read twice by the researchers in order to gain an appreciation of the scope of the data set. After that, initial codes were developed based on the data. Initial coding in an inductive thematic analysis is driven by the goal to remain open to all possible interpretations [21]. 
Thirdly, all of the codes were combined, and thematic relationships were identified. Themes are identified by "bringing together components or fragments of ideas or experiences, which often are meaningless when viewed alone" [22]

\section{Results}

The findings of the study are given here in relation to the sub-questions.

\section{How do Turkish and English primary education students perceive intelligence?}

The descriptive scores related to this question are given in Table-1.

Table 1. Arithmetic mean and standard deviation statistics of university students' intelligence perception

\begin{tabular}{|c|c|c|c|c|}
\hline & \multicolumn{2}{|c|}{ Entity } & \multicolumn{2}{c|}{ Incremental } \\
\hline & $\bar{x}$ & $\mathrm{df}$ & $\bar{x}$ & $\mathrm{df}$ \\
\hline $\begin{array}{c}\text { Turkish Students } \\
(\mathrm{N}=201)\end{array}$ & 15,63 & 5,29 & 11,92 & 4,37 \\
\hline $\begin{array}{c}\text { English Students } \\
(\mathrm{N}=114)\end{array}$ & 16,40 & 4,44 & 18,27 & 3,35 \\
\hline
\end{tabular}

When comparing the perception of intelligence scores, the entity (fixed mindset) scores are higher than the incremental (growth mindset) scores for Turkish students and the incremental scores are higher than the entity scores for English students.

To investigate the national differences in the students' perception of intelligence, the One Way Between Groups Multivariate Analysis Of Variance (MANOVA) was performed on the data obtained from the students of each country. Table 2 illustrates the MANOVA results which include the comparison of the scores in the intelligence perception.

Table 2. MANOVA results which show the comparison of total scores of university students' intelligence perception

\begin{tabular}{|c|c|c|c|c|}
\hline Wilks' Lambda & F & Hypothesis df & Error df & $\mathrm{p}$ \\
\hline, 614 & 98,277 & 2 & 312 &, 00 \\
\hline
\end{tabular}

When Table 2 is analyzed, the average scores for intelligence perception (Wilks' Lambda value, 614, F= $98,277, \mathrm{p}<.05$ ) show a significant difference of ,05 level. Table 3 illustrates the information about the comparison of the scores for the entity and incremental dimensions (two of the intelligence perception dimensions) of the students grouped by country.
Table 3. The results of multivariate analysis of variance (MANOVA) for each perception of intelligence in terms of country

\begin{tabular}{|c|c|c|c|c|c|c|}
\hline & $\begin{array}{c}\text { Type III } \\
\text { Sum of } \\
\text { Squares }\end{array}$ & df & $\begin{array}{c}\text { Mean } \\
\text { Square }\end{array}$ & F & $\mathrm{p}$ & Dif. \\
\hline Entity & 42,760 & 1 & 42,760 & 1,706 &, 192 & \\
\hline Error & 7843,926 & 313 & 25,060 & & & \\
\hline $\begin{array}{c}\text { Increm } \\
\text { ental }\end{array}$ & 2934,589 & 1 & 2934,589 & 180,269 &, 00 & t-e \\
\hline Error & 5095,297 & 313 & 16,279 & & & \\
\hline
\end{tabular}

The $\mathrm{F}$ test is included in Table 3 to compare the mean scores in the entity and incremental dimensions in terms of country. According to the MANOVA results, the mean scores of the students in the incremental dimension show a statistically significant difference in terms of country $(\mathrm{F}=180,269 \mathrm{p}<.05)$. However, no significant difference was found in the mean scores of students in the entity dimension in terms of country $(\mathrm{F}=1,706 \mathrm{p}<.05)$.

Due to the number of categories under three, the LSD test was used in order to find out which country showed the difference in the mean incremental dimension. When the incremental dimension scores were taken into account, a significant difference was found in favour of the English students.

\section{How do Turkish and English primary education students perceive intelligence, based on their gender?}

The descriptive scores related to this question are given in Table 4.

Table 4. Arithmetic mean and standard deviation statistics of university students' intelligence perception according to gender variable.

\begin{tabular}{|c|c|c|c|c|}
\hline & \multicolumn{2}{|c|}{ Entity } & \multicolumn{2}{c|}{ Incremental } \\
\hline & $\bar{x}$ & $\mathrm{df}$ & $\bar{x}$ & $\mathrm{df}$ \\
\hline Female for Turkey $(\mathrm{N}=132)$ & 15,91 & 5,32 & 12,22 & 4,23 \\
\hline Male for Turkey $(\mathrm{N}=69)$ & 15,10 & 5,24 & 11,33 & 4,51 \\
\hline Female for England $(\mathrm{N}=81)$ & 15,76 & 4,50 & 17,88 & 3,42 \\
\hline Male for England $(\mathrm{N}=33)$ & 17,96 & 3,94 & 19,21 & 3,01 \\
\hline
\end{tabular}

When comparing the perception of intelligence scores in terms of gender, the entity scores are higher than the incremental scores for the Turkish students and the incremental scores are higher than the entity scores for the English students. Table 5 illustrates the information about the comparison of the scores in the entity and incremental dimensions (two of the intelligence perception dimensions) by gender 
Table 5. The results of multivariate analysis of variance (MANOVA) of university students' intelligence perception according to gender variable

\begin{tabular}{|c|c|c|c|c|c|c|c|}
\hline & & $\begin{array}{l}\text { Type III Sum } \\
\text { of Squares. }\end{array}$ & df & Mean Square & $\mathrm{F}$ & $\mathrm{p}$ & Difference \\
\hline & Entity & 30,114 & 1 & 30,114 & 1,074 &, 301 & \\
\hline \multirow[t]{4}{*}{ Turkey } & Error & 5580,373 & 199 & 28,042 & & & \\
\hline & Incremental & 36,211 & 1 & 59,28 & 1,901 &, 170 & \\
\hline & Error & 3790,515 & 199 & 19,048 & & & \\
\hline & Entity & 113,926 & 1 & 113,926 & 6,020 &, 016 & $m-f$ \\
\hline \multirow[t]{3}{*}{ England } & Error & 2119,513 & 112 & 18,924 & & & \\
\hline & Incremental & 41,055 & 1 & 41,055 & 3,746 &, 055 & \\
\hline & Error & 1227,515 & 112 & 10,960 & & & \\
\hline
\end{tabular}

Due to the number of categories under three, the LSD test was used in order to find out which gender showed the difference in the entity dimension for the English students. When the entity scores were taken into account, a significant difference was found in favour of males. Also, there was not a statistically significant difference between males and females for the Turkish students.

\section{What views do Turkish and English primary education students hold about intelligence perceptions?}

To explore students' opinions about intelligence perceptions, semi-structured interviews were conducted with 10 ( 8 Turkish and 2 English) undergraduate students of education. 5 Turkish and 2 English students were female, and 3 Turkish students were male. The participants were aged between 21 and 23 .

Students' opinions about intelligence perceptions were categorized based on the content analysis. They were classed as entity and incremental under the themes. The distribution of the students' opinions about intelligence perceptions are shown in Table 6.

Table 6. Intelligence perceptions of students who are in primary education

\begin{tabular}{|c|c|c|c|c|c|}
\hline \multirow{2}{*}{ THEMES } & \multirow{2}{*}{ CODES } & \multicolumn{2}{|c|}{ Turkish Students (8) } & \multicolumn{2}{|c|}{ English Students (2) } \\
\hline & & f & $\%$ & $\mathrm{f}$ & $\%$ \\
\hline \multicolumn{2}{|c|}{ Number of students who adopt entity } & 6 & 60 & 1 & 10 \\
\hline \multirow{9}{*}{ ENTITY } & $\begin{array}{l}\text { Born with certain intelligence and it } \\
\text { can't change }\end{array}$ & 4 & 40 & 1 & 10 \\
\hline & Look smart & 2 & 20 & - & - \\
\hline & Effortless & 5 & 50 & 1 & 10 \\
\hline & $\begin{array}{l}\text { Tendency to give up and } \\
\text { disappointment }\end{array}$ & 4 & 40 & 1 & 10 \\
\hline & Workload & 1 & 10 & - & - \\
\hline & $\begin{array}{l}\text { Decrease in grades during times of } \\
\text { adversity }\end{array}$ & 1 & 10 & - & - \\
\hline & Focusing get a high score & 1 & 10 & - & - \\
\hline & Don't take responsibility & 1 & 10 & - & - \\
\hline & $\begin{array}{l}\text { Using math as a criterion of } \\
\text { intelligence }\end{array}$ & 4 & 40 & - & - \\
\hline \multicolumn{2}{|c|}{ Number of students who adopt incremental } & 2 & 20 & 1 & 10 \\
\hline \multirow{5}{*}{ INCREMENTAL } & $\begin{array}{l}\text { Intelligence is not fixed and can be } \\
\text { improved }\end{array}$ & 2 & 20 & 1 & 10 \\
\hline & Having desire to learning & - & - & 1 & 10 \\
\hline & Effort & 2 & 20 & 1 & 10 \\
\hline & Work harder & 1 & 10 & 1 & 10 \\
\hline & $\begin{array}{l}\text { Increase in grades during times of } \\
\text { adversity }\end{array}$ & 1 & 10 & - & - \\
\hline
\end{tabular}


With reference to Table 6,7 of the 10 students were found to hold broadly entity beliefs, and 3 of the 10 students were broadly to adopt broadly incremental beliefs. Direct quotations related to the entity and incremental themes are given below:

\section{Students Talking about Entity Beliefs}

\section{EFS1(English Female Student) :}

... So I believe that some people do have a limit to which they can understand. That's why some of us are more intelligent than others...

---- I think that mostly we're born with it, maybe I just haven't been challenged. Maybe I haven't challenged myself enough, do you know what I mean: I stick to my comfort zone...

\section{TFS1(Turkish Female Student) :}

...Intelligence is an inborn trait... When I observe generally Medical faculty, Law Faculty students and the parents of my friends who will study in these faculties, they are probably the children of doctors, engineers, lawyers etc. In my opinion they are intelligent as inborn or maybe they will develop themselves later, but even so, intelligence is inborn. Compared to my other friends in primary school, I was good at verbal lessons, but I had difficulty in Math, although I got extra private lessons for Math I am still not good at it which means I am not much intelligent. For example, although I increased my grade from zero to five or ten, I could not increase it to twenty that means I am not good at it, so my motivation decreased and I gave up...

\section{TMS3(Turkish Male Student) :}

...I think intelligence is an absolutely inborn trait. At first, when children study at primary school or secondary school they are influenced by their teachers, they aren't under much pressure and don't have many lessons; but at high school there are lots of subjects, students do not care for their teacher much or they are not influenced by their teacher. They have plans for the future, they think logically. So what I mean is that the successful student at primary or secondary school cannot be successful at high school. Until high school, even students who are not intelligent can be successful, but later they can't do well if they are not intelligent. There is lots of responsibility and pressure (lessons and subjects). so intelligence is an important factor for these things. All people around me said that I was intelligent, as I never studied but I succeed in lots of things...

\section{Students Talking about Incremental Beliefs}

\section{EFS1(English Female Student) :}

...I think everybody's born with a level of intelligence. I think it depends how much you work at it to develop that intelligence. I think that everybody's got - a mindset which is determined when you're younger, depending on how - I suppose how you've been brought up, how you look at things; but if you're willing to work at something -- I know for me, I have to work at things - but if you're willing to work, you reap the rewards. It's more about self - pushing, I guess.

I think you can make yourself more intelligent. I think it's just again how much you want to push yourself to make yourself that person you want to be...

\section{TFS3(Turkish Female Student) :}

... I think being intelligent can be directed or improved and if people are guided well, they can do better things. I was good at Math, but I also had some problems in some topics, I had difficulty in Physics, I am still not good at it. For example, I got 30 or 40 at $9^{\text {th }}$ grade but I studied and I got 90 . But, I think it's about the difficulty level of the exam I have still some problems about it, I know myself...

\section{Factors that Affect and Shape Students' Opinions about Intelligence Perceptions}

In order to identify factors that affect and shape students' opinions about intelligence perceptions, the data from the interviews was coded under the themes of "teachers" behaviour" and "family". The distribution of the students' opinions about intelligence perceptions in relation to these themes is shown in Table 7.

Table 7. Factors that affect and shape students' opinions about intelligence perceptions

\begin{tabular}{|c|c|c|c|c|c|}
\hline \multirow{2}{*}{ THEMES } & CODES & \multicolumn{2}{c|}{$\begin{array}{c}\text { Turkish } \\
\text { Students } \\
\text { (8) }\end{array}$} & \multicolumn{2}{c|}{$\begin{array}{c}\text { English } \\
\text { Students } \\
\text { (2) }\end{array}$} \\
\cline { 2 - 6 } & & $\mathrm{f}$ & $\%$ & $\mathrm{f}$ & $\%$ \\
\hline \multirow{2}{*}{$\begin{array}{c}\text { Teachers } \\
\text { Behavior }\end{array}$} & Negative attitude for entity & 6 & 60 & - & - \\
\cline { 2 - 6 } & $\begin{array}{c}\text { Make a distinction between } \\
\text { students }\end{array}$ & 3 & 30 & - & - \\
\cline { 2 - 6 } & $\begin{array}{c}\text { Positive attitude for } \\
\text { incremental }\end{array}$ & 1 & 10 & - & - \\
\hline \multirow{2}{*}{ Family } & Negative attitude for entity & 2 & 20 & - & - \\
\hline
\end{tabular}

According to Table 7, 7 of the 10 students stated that teachers' negative attitudes had influenced their adoption of entity beliefs, and 1 student stated that teachers' positive attitudes had influenced his/her adoption of incremental beliefs. Also, 3 of the 10 students stated that teachers made a distinction between students (based on their perceived intelligence), and 2 of the 10 students stated that the teachers' use of praise influenced their adoption of entity beliefs. Direct quotations related to these themes are given below:

\section{Students Talking about the Influence of Teachers and Family's Behaviour}

\section{TMS2(Turkish Male Student):}

....one of the reasons that I do not like Math was my teacher's behaviour towards me. I was 9 years old at 3rd grade, my teacher was so rude towards me in front my 
friends and I disliked Math. I felt that I was not intelligent, I felt I was incompetent because of that event. Also, the first time I had a Math exam and I got poor grade, my father scolded me. So I never liked Math. It was a disappointment for me.

\section{TFS2(Turkish Female Student):}

...My teachers were not efficient, there was also discrimination between the hardworking students and the other ones. Teachers always paid attention to the intelligent, competent students. They always loved and really cared for them and they focused on them. I do not know the reason. These kind of things resulted as a lack of self-confidence. I was not interested in lessons.

\section{TMS2(Turkish Male Student):}

...I was at secondary school and when I got low grade at math, I believed that I was not intelligent; but when I started high school, I also got extra lessons and I recognized that I could do better at Math. As I went to a math course and paid money, those teachers behaved us better and cared us positively. But at public school that was not like that. I was always sat in the rear row of seats and I skipped lessons. My father tried to help me and I felt really bad. It was a kind of learned helplessness. The teacher always cared for certain kinds of students: he/she ignored those like me. So I got angry and I did not study. I thought that I had a problem about my intelligence level. I believed that I could never be good at this. The teacher was an important factor. But at high school I was better. The teacher always tried to help us, he/she tried to satisfy all students and cared for all of us. After that I could do better at Math...

\section{Conclusion and Discussion}

The social-cognitive motivation theory developed by Carol Dweck is about learners' beliefs about the nature of intelligence. According to this theory, there are two different perceptions of intelligence: that intelligence is largely fixed, stable and resistant to change (entity theory or fixed mindsets) and that intelligence is fluid, malleable and open to change (incremental theory or growth mindsets) [1] The findings of this study reveal that the Turkish students' average score in relation to entity intelligence theory is higher than that which relates to incremental intelligence theory, and the English students' average score regarding incremental intelligence theory is higher than that relating to entity intelligence theory. In addition, when comparing the average score in relation to incremental intelligence theory, the scores of the English students are significantly higher than those of the Turkish students. These results are consistent with the findings of the existing literature ([14]; [2]. It is possible that sociocultural factors are strongly implicated in these results, as the average scores of the entity-fixed intelligence dimension are consistently high for Turkish students. It is possible that if, from their children's infancy onward, Turkish parents show pride in children's behaviours which they associate with intelligence, this will affect the higher average scores of the entity-fixed intelligence dimension [2]. The socio-cultural factors which influence the students' perception of intelligence could usefully be the subject of more extensive research.

When the gender variable was taken into account, the male English students were found to be significantly more likely to hold entity beliefs than the female students. There was not a statistically significant difference between males and females for the Turkish students. When the general literature was examined, it was found that gender is not a reliable predictor of mindset [23]

With regard to the semi-structured interviews, when the students' answers about perceptions of intelligence are analyzed, it was found that the codes which emerged had parallels in the existing literature [1];[4] [6]; [24]. One of the most interesting findings is that students (4 Turkish students) stated that being able to understand maths is an indicator of intelligence. An examination of the literature reveals that the relation between success in school and students' perception of intelligence has often been explored, but how "success" or "failure" in different subjects affects the students' perception of intelligence has not been examined. So, future quantitative and qualitative studies on how success in different subjects affects the mindset of students could be undertaken.

One of the important themes emerging from the semi-structured interviews is that of teacher attitudes and the effect of praise on the students' views of intelligence. These findings are consistent with those of Mueller, C. M., \& Dweck, C. S. [25] whose study concluded that teacher praise had a dramatic effect on the students' mindset. Praising students for their ability encouraged a fixed mindset and created vulnerability, but praising them for their effort or the strategy they used encouraged a growth mindset and fostered resilience.

Therefore, early in their course of study, it is suggested that student teachers should be introduced to Dweck's mindset theory [1]. Teacher education programmes could include the initial identification of students' beliefs about intelligence and their learning orientation. The students should then be encouraged to reflect on their own beliefs and learning behaviours and those of their pupils. In particular, given the demonstrable value of high quality feedback strategies and the role of metacognition in learning (summarised in Hattie, [26]; [27]), teacher trainees should be shown how to teach their pupils to think explicitly about their thinking, and learn about how best they learn.

\section{REFERENCES}

[1] Dweck, C. (2000). Self-Theories: Their Role in Motivation, Personality and Development. Philadelphia: Psychology Press 
[2] İlhan-Beyaztaş, D. and Hymer, B. (2016). 'An analysis of Turkish students' perception of intelligence from primary school to university'. Gifted Education International, 0261429416649041, first published online on May 16, 2016.

[3] Sternberg, R. (1997). Successful Intelligence: How Practical and Creative Intelligence Determine Success in Later Life. New York and London: Penguin

[4] Dupeyrat, C. and Mariné, C. (2005). 'Implicit theories of intelligence, goal orientation, cognitive engagement, and achievement: a test of Dweck's model returning to school adults'. Contemporary Educational Psychology, 30: 43-59.

[5] Blackwell, L.S., Trzesniewski, K.H. and Dweck C.S. (2007). 'Implicit theories of intelligence predict achievement across transition: a longitudinal study and an intervention'. Child Development 78(1): 246-263.

[6] Hymer, B . and Gershon, M. (2014). Growth Mindset Pocketbook. Alresford: Teachers' Pocketbooks

[7] Renaud-Dube, A., Talbot, D., Taylor, G., \& Guay, F. (2015). The relations between implicit intelligence beliefs, autonomous academic motivation, and school persistence intentions: A mediation model. Social Psychology of Education: An International Journal, 18, 255-272. doi: 10.1007/s11218-014-9288-0

[8] Lynott, D.J. and Woolfolk. A.E. (1994). 'Teachers' implicit theories of intelligence and their educational goals'. Journal of Research and Development in Education. 27(Summer), 253-264.

[9] Lee, K. (1996). 'A study of teacher responses based on their conceptions of intelligence'. Journal of Classroom Interaction, 31(Summer), 1-12.

[10] Butler, R. (2000). 'Making judgments about ability: the role of implicit theories of ability in moderating inferences from temporal and social comparison information'. Journal of Personality and Social Psychology, 78: 965-978.

[11] Poliquin, A.M. (2010). 'Exploring preservice teachers' views of intelligence' (2010). UNLV Theses/Dissertations /Professi onal Papers/Capstones. Paper 820.

[12] Jones, B.D., Bryant, L.H., Snyder, J.D. and Malone, D., (2012). 'Preservice and inservice teachers' implicit theories of intelligence'. Teacher Education Quarterly, 39 (2), 87-101.

[13] Gutshall, C. A. (2014). 'Pre-Service Techers' Mindset Beliefs about Student Ability'. Electronic Journal of Research in Educational Psychology, 12(3), pp.785-802

[14] Asbury, K., Klassen, R., Bowyer-Crane, C.., and Nash, P. (2015). 'National Differences in Mindset Among Students Who Plan to Be Teachers'. International Journal of School \& Educational Psychology, p.1-7 Available at: http://www.tandfonline.com/doi/full/10.1080/21683603.201 5.1075164 (Accessed 8 June 2016)

[15] Köksal, N. and Convery, A. (2013). 'Initial Teacher Education in Turkey and England: Comparing Competencies and Standards'. Journal of Education and Future, 3, 1-20

[16] European Commission (2005). Common European Principles for Teacher Competences and Qualifications. Available at: http://www.atee1.org/uploads/EUpolicies/common_eur_prin ciples_en.pdf (Accessed 7 June 2016)

[17] Turkish Republic Ministry Of National Education (2006). Generic Teacher Competencies Available at: http://otmg.meb.gov.tr/belgeler/otmg/Generic_Teacher_Com petencies.pdf (Accessed 7 June 2016).

[18] National Union of Teachers, (2002). NUT Briefing On "Qualifying To Teach": Professional Standards For Qualified Teacher Status And Requirements For Initial Teacher Training 2002. Available at: https://www.teachers.org.uk/files/active/0/QTS_Standards.p df (Accessed 7 June 2016)

[19] Training and Development Agency for Schools (2008). Professional Standards for Qualified Teacher Status and Requirements for Initial Teacher Training. London: TDA. Available at:https://www.rbkc.gov.uk/pdf/qts-professional-standards-2 008.pdf (Accessed 7 June 2016)

[20] Department for Education (2011). Teachers' Standards. Available at:https://www.gov.uk/government/publications/teachers-sta ndards (Accessed 7 June 2016)

[21] Douglas, H. A. (2008). 'The effect of brca gene testing on family relationships: a thematic analysis of qualitative interviews'. University of Pittsburgh, unpublished master thesis.

[22] Leininger, M. M. (1985). "Ethnography and ethnonursing: Models and modes of qualitative data analysis". In M. M. Leininger (Ed.), Qualitative research methods in nursing (pp. 33-72). Orlando, FL: Grune \& Stratton.

[23] Verniers, C. and Martinot, D. (2015). 'Perception of students' intelligence malleability and potential for future success: unfavourable beliefs towards girls'. British Journal of Educational Psychology, 85: 1-11.

[24] Yeager, D. S., Paunesku, D., Walton G. M., and Dweck, C.S. (2013). 'How can we instill productive mindsets at scale? A review of the evidence and an initial R\&D agenda'. White paper prepared for the White House meeting on Excellence in education: The importance of academic mindsets. May 10, 2013.

[25] Mueller, C.M., and Dweck, C.S. (1998). Praise for intelligence can undermine children's motivation and performance. Journal of Personality and Social Psychology, 75, 33-52.

[26] Hattie, J. (2009). Visible Learning - A synthesis of over 800 meta-analyses relating to achievement. Abingdon: Routledge

[27] Hattie, J. (2012). Visible Learning for Teachers - Maximising impact on learning. Abingdon: Routledge.. 